\title{
Exploring the possibilities of remote yield estimation using crop water requirements for area yield index insurance in a data-scarce dryland
}

\section{Emmanuel Eze ( $\nabla$ eze.emma@unn.edu.ng )}

University of Nigeria, Nsukka https://orcid.org/0000-0003-2007-2696

\section{Atkilt Girma}

Mekelle University

Amanuel Zenebe

Mekelle University

Jean Moussa Kourouma

Copperbelt University, Zambia

Gebreyohannes Zenebe

Mekelle University

\section{Research Article}

Keywords: Area yield index insurance, Barley, CROPWAT, crop yield, Tigray, Ethiopia

Posted Date: May 13th, 2020

DOl: https://doi.org/10.21203/rs.3.rs-28663/v1

License: (c) (i) This work is licensed under a Creative Commons Attribution 4.0 International License. Read Full License

Version of Record: A version of this preprint was published on August 31st, 2020. See the published version at https://doi.org/10.1016/j.jaridenv.2020.104261. 


\title{
Exploring the possibilities of remote yield estimation using crop water requirements for area yield index insurance in a data-scarce dryland
}

\begin{abstract}
The need for accurate and meaningful agricultural data as the means of making vibrant policies and informed decisions, is an increasing concern for policymakers in developing countries such as Ethiopia, where such information is usually scarce. In Ethiopia, the impacts of climate change on crops yields is rarely available at the lowest administrative levels such as wards/villages, for the benefits of the grassroots' populace. Thus, this research sought to evaluate the use of crop water requirements in the estimation of crops' yield. FAO's CROPWAT 8.0 application was used to pre-determine the possibility, preceding the use of CROWRAYEM. Both CROPWAT and CROWRAYEM had high coefficients of determination, when tested with a survey data of barley and sorghum farmers' yield for the 2015 to 2018 cropping season in semi-arid southern Tigray, northern Ethiopia. Furthermore, the infusion of the crop yield into a recently published area yield index insurance payout structure, increases the functionality of the proposed yield estimated model (CROWRAYEM).
\end{abstract}

Keywords: Area yield index insurance; Barley; CROPWAT; crop yield; Tigray; Ethiopia

\section{Introduction}

Agriculture has been generally accepted as the mainstay of developing economies. Its multiple outputs are basic sustaining provisions for mankind's nutrition and food security. The Ethiopian economy greatly benefits from the agriculture sector, receiving a contribution of about $49 \%$ to her GDP (Gross Domestic Product), attracting over $80 \%$ of foreign 
exchange, and actively engaging around $80 \%$ of the population (CSA, 2014). It behooves all stakeholders to ensure the continual increment and improvement in agricultural outputs despite prevalent climate change. Adverse impacts of climate change on agricultural yields in developing countries is indisputable.

Crop yield data is required for pertinent decisions and policymaking at various levels. Such data ought to be available at the lowest administrative levels such as wards/villages for the benefits of the grassroots' populace. Sadly, such data are unavailable generally in developing countries(Jones et al., 2011; Miranda and Farrin, 2012). Alternatively, several techniques of crop forecasting and estimation have emerged in literature. Crop cut, farmer's estimate, sampling harvest unit, whole plot harvest, expert assessment, crop cards, crop modelling, purchaser's/insurance record, allometric models and remote sensing are identified as stateof-the-art methods of crop yield estimate in the work of (Sapkota et al., 2016). Furthermore, crop forecasting and estimation techniques were recognized as being very important for development of government policies to advance crop production by (Maurya et al., 2019). All crops require sufficient water supply at critical stages of their growth and development. Bearing in mind that not all supplied water are effectively utilized by crops due to evapotranspiration, the concept of crop water requirement emanates, which Allen et al., (1998) describes as the amount of water required to meet crops' evapotranspiration needs,. In the assessment of crop growth simulation models Khan and Walker (2015) conclude that CROPWAT has advantage over EPIC ${ }^{1}$ and DSSAT ${ }^{2}$ models, with significant advantages in data-scarce developing countries.

Generally, there is a consensus that the computer software "CROPWAT", developed by FAO, is a decision support tool for the estimation of water requirements of crops based on 
their evapotranspiration, to facilitate planning of water management, and the scheduling of irrigation in the event of rainfall deficits (Bhat et al., 2017; Ewaid et al., 2019; Khan and Walker, 2015). No doubt, the use of the CROPWAT model has given rise to improved decisions and practices in terms of timely and appropriate and supplemental irrigation practices. However, most studies have limited their scope of the application of the CROPWAT model to estimating crop water requirements (Bhat et al., 2017; Yazew et al., 2012), irrigation scheduling (Berhane et al., 2010), and yield response and reduction (Loum et al., 2014); combination of crop water requirement and yield reduction (Bana et al., 2013); crop water requirement and irrigation schedules (Ewaid et al., 2019; Surendran et al., 2017). This study explores the use of crop water requirement of barley and sorghum in estimating farmers' yield and yield losses. This idea is considered novel in the Ethiopian context, as no other known work has attempted yield estimation using our approach. The models were validated and found highly promising, especially with use for remote calculation of the area's yield insurance payouts based on an earlier work of Eze et al. (2020). A study as this will address the expressed shortcoming of index insurance as lacking empirical validation and monitoring of experiences, in data scarce regions (Clarke, 2016)n. Our methods are presented in simple, explicit steps and could aid the replication of such a study anywhere in the world.

\section{Research methods}

\subsection{The study area}

The study was undertaken in two selected woredas (districts) of Tigray region, Ethiopia. Purposive sampling approach was adopted in selecting the study communities based on their contribution to the regional and national food security. The study area is located between 
$12^{\circ} 38^{\prime} 44^{\prime \prime} \mathrm{N}$ to $12^{\circ} 57^{\prime} 10^{\prime \prime} \mathrm{N}$ Latitude and $39^{\circ} 27^{\prime} 18^{\prime \prime}$ E to $39^{\circ} 55^{\prime} 56^{\prime \prime}$ E Longitude, with an altitude ranging from 1507 to $3760 \mathrm{~m}$ above sea level (m.a.s.l.).

The agro-climatology of the study area is classified as semi-arid, predominantly with irregular rainfall accompanied by frequent droughts. From analysis of climate data obtained, the mean annual temperature of the area is between $13{ }^{\circ} \mathrm{C}$ and $29^{\circ} \mathrm{C}$. Although annual rainfall ranges from $624 \mathrm{~mm}$ to $827 \mathrm{~mm}$, the average annual rainfall is around $725 \mathrm{~mm}$. Place of higher altitudes within the area have a bimodal rainfall type with the main rainy season, which lasts from June to September (locally called "Kiremt"), and the shorter rainy season, February to May, (locally called "Belg"). Four traditional agro-ecological divisions are used for categorization in Ethiopia namely: Kola (lowland 1400-1800 m.a.s.l.), Woina-dega (midland 1800-2400 m.a.s.1.); Dega (highland 2400-3400 m.a.s.l.) and Wurch (very-cold highlands above 3400 m.a.s.l.). However, only the Kola and Dega agro-ecological divisions are found in the study area (Table 1). 


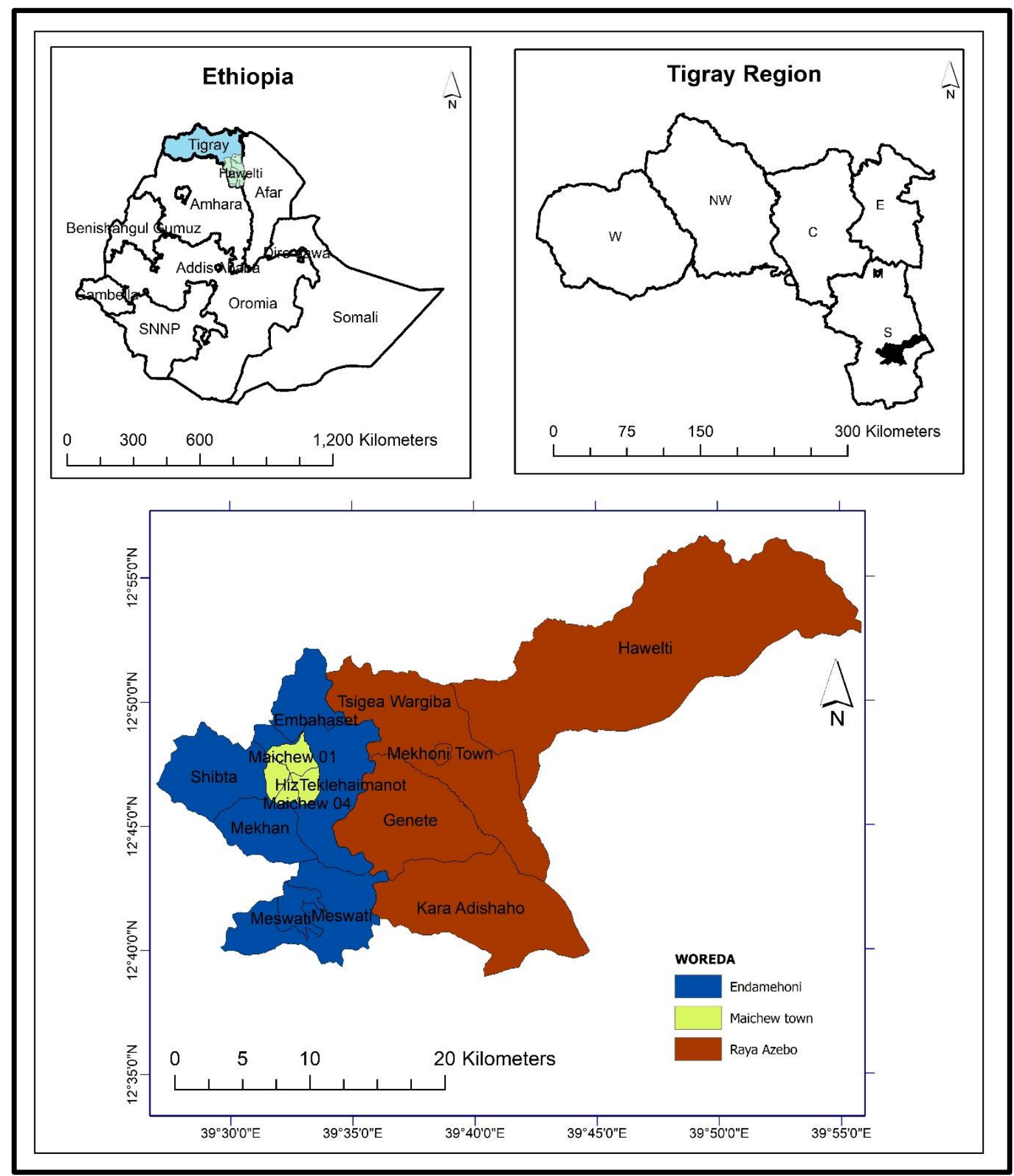

Figure 1: Study area map 
Table 1: Agro-ecology of wards (tabias) used in this study

\begin{tabular}{llll}
\hline Woreda (district) & Tabia/Kebele (ward) & $\begin{array}{l}\text { Height } \\
\text { (m.a.s.l.) }\end{array}$ & Remarks \\
\hline Endamekhoni & Meswaeti & $2441-2446$ & Dega (highland) \\
Endamekhoni & Shibta & $2539-2621$ & Dega (highland) \\
Endamekhoni & Hizba Teklehaimanot & $2358-2496$ & Dega (highland) \\
Endamekhoni & Embahasti & $2683-2884$ & Dega (highland) \\
Endamekhoni & Mekhan & $1778-1795$ & Kola (lowland) \\
Raya Azebo & Kara Adishahu & $1560-1763$ & Kola (lowland) \\
Raya Azebo & Genete & $1731-1864$ & Kola (lowland); \\
Raya Azebo & Tsigea & $1550-1724$ & Kola (lowland) \\
Raya Azebo & Hawelti & $1628-1758$ & Kola (lowland)
\end{tabular}

\subsection{Data acquisition}

\subsubsection{Yield data (2015-2018)}

This data collected in the first quarter of 2019, was from a direct interview of farmers, in lieu of historical yield data unavailable at ward and district levels. An IPAQ device was used for delineation of agricultural fields to aid the collection of increasingly accurate field area and realistic crop yield measurements from farmers. Thirty-four (34) farm owners (sorghum $=16$; barley $=18$ ) engaged in only rain-fed cropping in the highland and lowland areas are used for this study. Although more farm fields were randomly selected, only famers who could provide history of crop yield obtained in the last four years were eventually included. In most cases also, farmers were found in pairs and groups of at least three, hence there is a 
strong influence of group consensus on farmers' responses, hence increasing the accuracy of the farmers' memory-based crop yield data. The unit of measurement of crop yield is in Quintals per hectare (Qt/Ha).

Barley and Sorghum were purposively selected as the subject of this study due to their nutrition value and their daily intake in Ethiopia. Also, Barley is the major cultivated crop in Endamekhoni, due to agro-climatic factors and an available ready market in the beer factory nearby; while sorghum is popular in Raya Azebo for agro-climatic reasons, and as a cushion effect on availability of livestock feed in the event of drought. These reasons necessitated the restriction of this study to the most commonly cultivated crops, and also to increase the accuracy of yield recall from farmers' memory. Barley was therefore selected for consideration in Endamekhoni district and sorghum in Raya Azebo district. According to Shuai et al. (2018), barley, sorghum, teff, maize, wheat are referred to be the core of the Ethiopian food economy, covering about $75 \%$ of the total cultivated area. These reasons necessitated the restriction of this study to the most commonly cultivated crops, and also to increase the accuracy of yield recall from farmers' memory.

\subsubsection{Meteorological data (2015-2018)}

The Climate Hazards group InfraRed Precipitation with Stations (CHIRPS) grid precipitation dataset from 2015 to 2018, obtained from the IRI Data Library (ftp://ftp.chg.ucsb.edu/pub/org/chg/products/CHIRPS-2.0/) was used for this study. The CHIRPS is described as a combination of a "high-resolution climatology, time-varying cold cloud duration precipitation estimates, and in situ precipitation estimates", and holds very low errors, yet of high research quality(Funk et al., 2014; Shukla et al., 2017). The CHIRPS being a grid-based data is preferred to the point-station precipitation data for use in this 
study, because it is highly reliable and provides data even for areas without a meteorological station and has been proven as accurate for use in Ethiopia by (Bayissa, 2018; Gebrechorkos et al., 2018).

The daily Enhancing National Climate Services (ENACTS) maximum and minimum temperature data (2015-2018) was obtained from the Ethiopian National Meteorological Agency (NMA), and used for this study. From the global ENACTS data (http://iri.columbia.edu/resources/enacts/) NMA refined it further using several in-situ stations in Ethiopia. Further details on the production of this temperature data has been described by International Research Institute for Climate and Society (2016) as being generated from the combination of observation records, digital elevation models and reanalysis products for temperature, hence considered appropriate for this study being highly reliable.

\subsubsection{CROPWAT 8.0 data}

CROPWAT 8.0 is one of the popular decision-support software, developed for the Water Resources Development and Management Service of the Food and Agriculture Organization (FAO). It is computer program comprised of a number of procedures, algorithms and documentation for use in the calculation of reference evapotranspiration (ETo), crop water requirement (CWR), irrigation scheduling, and irrigation water requirement of crops by providing climate, rainfall, crop, and soil data.

The climate data (temperature and rainfall data) were sourced from the IRI Data Library and resources page; while the crop data for the crops of interest (barley and sorghum), were derived from the FAO 56 Manual (Allen et al., 1998), and served as input into relevant fields of the software. Soil data used for the area include black clay soil for (Endamekhoni) and 
Red sandy loam soil for Raya Azebo. Planting dates were obtained from farmers during the survey.

\subsection{Model efficiency evaluation}

Four statistical analyses were implemented to evaluate the performance of both CROPWAT 8.0 and Crop water requirement yield estimation model. These are the coefficient of determination $\left(R^{2}\right)$, root mean square error (RMSE), mean absolute error (MAE) and the index of agreement $(d)$.

$R^{2}=\left(\frac{\sum(X-\bar{X})(Y-\bar{Y})}{\sum(x-\bar{x})^{2} \sum(y-\bar{y})^{2}}\right)^{2}$

$R M S E=\sqrt{\frac{1}{N} \sum(P i-O i)^{2}}$

$M A E=\sqrt{\frac{1}{N} \sum_{i=1}^{n}|P i-O i|}$

$d=1-\left[\frac{\sum_{i=1}^{n}(P i-O i)^{2}}{\sum_{i=1}^{n}(|P i-\bar{O}|+|O i-\bar{O}|)^{2}}\right]$

Where $P i$ is the predicted yield values and $O i$ is the farmers' reported yield values

The $R^{2}$ (equation 1) is the square of the Pearson's product moment correlation of simulated and recorded yield. This can be interpreted as how well the models explains variation in farmers' reported yield. The RMSE (equation 2), which squares the errors and returns positive numbers is used to rule out the problem of over- and under- predictions by the models. However, due to the use of average squared differences by RMSE, large differences are usually weighted more heavily. The $M A E$ (equation 3) overcomes the overweighting of large differences by the RMSE by taking averages of absolute errors. Both the RMSE and $M A E$ provide information about the efficiency of a model, with desired values being close 
to 1 (Chai and Draxler, 2014; Willmott and Matsuura, 2005). The index of agreement (d) (equation 4) by Willmott, (1981) ranges from 0 to 1 with higher index values indicating that the estimated yield values have better agreement with the farmers' reported yield values for the year under review. This study adopts a category of designation of $d$ by Clarke (2017) and (Liu et al., 2017) viz: "excellent"- $(d>0.9)$; "good"- $(0.8 \leq d<0.9)$, "moderate"- $(0.7 \leq d<0.8)$, and "poor"- $(d<0.7)$.

\section{Data analyses and results}

\subsection{Preliminary analyses}

The crop irrigation schedule was computed for each famer based on the required parameters, using the CROPWAT 8.0 software. Our interest was to obtain scientifically derived yield reductions emanating from rainfall deficiency (Figure 2), based on the crop water requirements of each specified crop, for all farmers surveyed for the years under review $(2015-2018)$.

\begin{tabular}{|c|c|c|c|c|c|c|}
\hline ETo station Endamehoni & \multicolumn{2}{|c|}{ Crop Barley } & \multicolumn{3}{|c|}{ Planting date $15 / 06$} & \\
\hline Rain station Endamehoni & Soil & LYY SOIL & \multicolumn{3}{|c|}{ Harvest date $12 / 10$} & \\
\hline \multicolumn{7}{|l|}{ Y Yield reductions } \\
\hline Stagelabel & $\mathbf{A}$ & B & C & D & Season & \\
\hline Reductions in ETc & 12.9 & 35.5 & 27.5 & 35.7 & 30.0 & $\%$ \\
\hline Yield response factor & 0.20 & 0.60 & 0.50 & 0.40 & 1.00 & \\
\hline Yield reduction & 2.6 & 21.3 & 13.8 & 14.3 & & $\%$ \\
\hline Cumulative yield reduction & 2.6 & 23.3 & 33.9 & 43.3 & 30.0 & $\%$ \\
\hline
\end{tabular}

Figure 2: Results of interest in the crop irrigation schedule of CROPWAT 8.0

Following the computation of the cumulative yield reduction (in percentage $(\%)$ ), yield values were computed for each farmer, based on the average expected crop yield during 
years of normal precipitation and optimum harvest. Thus, we derived "CROPWAT yield data", in addition to the farmers' survey crop yield data for correlation analyses. A plot was made with both datasets to produce a trend line, with a linear equation and coefficient of determination $\left(\mathrm{R}^{2}\right)$ generated (Figure 3 and 4 ). The estimated yield was evaluated using relevant statistics (Table 2). 


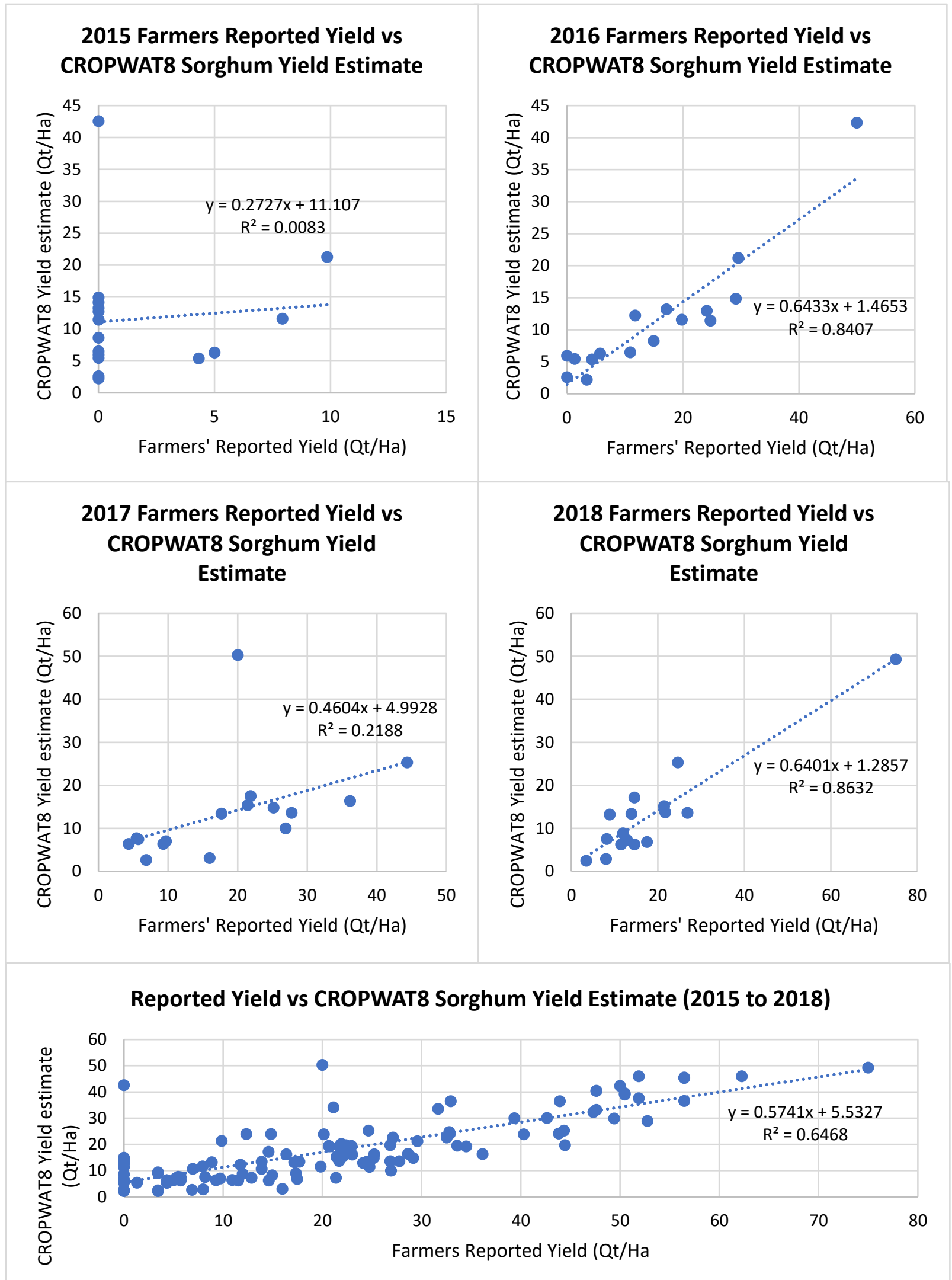

Figure 3: Farmers' reported yield vs CROPWAT estimated yield for sorghum 


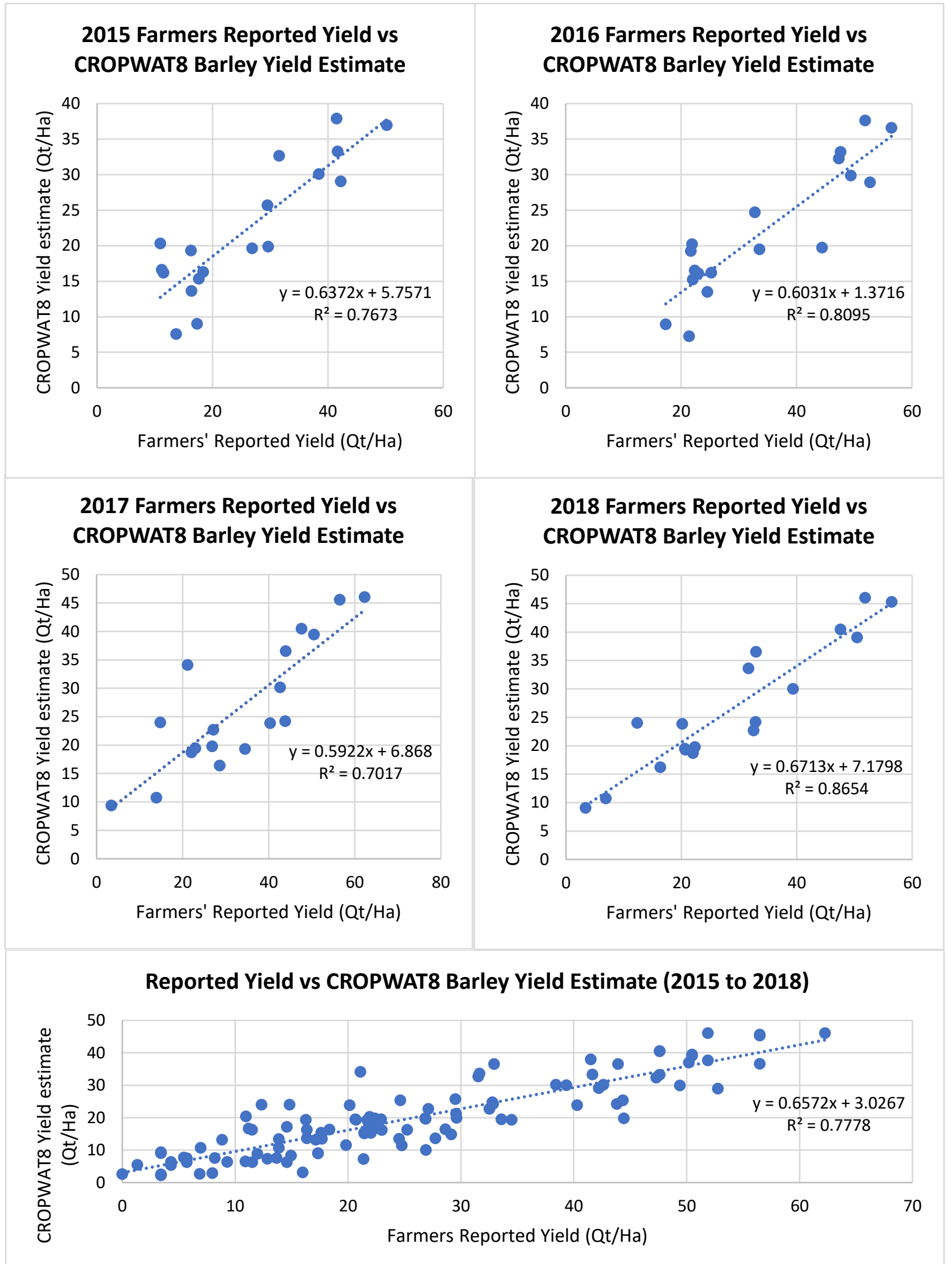

Figure 4: Farmers' reported yield vs CROPWAT estimated yield for barley 
Table 2: Statistical evaluation of CROPWAT8 estimated and farmers' reported crop yield

\begin{tabular}{|c|c|c|c|c|c|}
\hline \multirow{2}{*}{$\begin{array}{l}\text { Location/ } \\
\text { Crop }\end{array}$} & \multirow{2}{*}{$\begin{array}{l}\text { Model Evaluation } \\
\text { Statistics }\end{array}$} & \multicolumn{4}{|c|}{ Years } \\
\hline & & 2015 & 2016 & 2017 & 2018 \\
\hline \multirow{4}{*}{ Raya Azeb } & R-square & 0.008 & 0.83 & 0.16 & 0.85 \\
\hline & RMSE & 12.07 & 9.30 & 11.37 & 11.63 \\
\hline & MAE & 10.48 & 7.76 & 8.84 & 6.67 \\
\hline & $\mathrm{IA}(d)$ & 0.04 & 0.75 & 0.51 & 0.73 \\
\hline \multirow{4}{*}{ Endamekh } & R-square & 0.75 & 0.80 & 0.68 & 0.86 \\
\hline & RMSE & 11.26 & 18.72 & 16.49 & 12.23 \\
\hline & MAE & 9.89 & 17.59 & 14.47 & 9.41 \\
\hline & IA $(d)$ & 0.70 & 0.45 & 0.60 & 0.73 \\
\hline
\end{tabular}

Table 2 shows different spatiotemporal performances of CROPWAT 8.0 in estimating crop yield in the study area. For sorghum crops in Raya Azebo, the model performs badly in drought years (2015 and 2017) as indicated by very low coefficient of determination $\left(\mathrm{R}^{2}\right)$ and index of agreement $(d)$ and is good in years of (above)normal precipitation and yield. conversely, in Endamekhoni, the coefficient of determination $\left(\mathrm{R}^{2}\right)$ indicate a very strong prediction of farmers' reported yield ranging from $68 \%$ to $86 \%$ estimations.

\subsection{Crop water requirement analysis yield estimation model (CROWRAYEM)}

Following a strong relationship between predicted results in CROPWAT8 and farmers' reported yield in most of the years (Figures 3 and 4), a CROWRAYEM model is here tested for remote yield forecast based on climatic data and the crops' yield response factors of the earlier specified crops (barley and sorghum) within the study area. This model adopts the 
basic scientific procedure of FAO's CROPWAT, except the exclusion of the soil component in estimating yield. Solar radiation and temperature (minimum and maximum) data were used to compute potential evaporation (ETo). Multiplication of the ETo with the number of days within the crops' growing season gave rise to actual evapotranspiration (ETm). The product of the crop coefficient $(\mathrm{Kc})$ with ETm arrives at the crop water requirement (CWR) of the crop.

Furthermore, from the rainfall data ( $\mathrm{Rf}$ ), effective rainfall (Peff) is determined using (Rf*0.7). Moisture deficit (Def) is consequently obtained from deducting Peff from CWR. Yield response to moisture deficit (Yr) is then calculated and the value multiplied by the maximum yield potential of the crop to determine its yield value (CWR yield) (Figure 5). Results of the estimated yield of sorghum and barley are plotted (Figure 6 and 7), and compared for an evaluation of the performance (Table 3). 


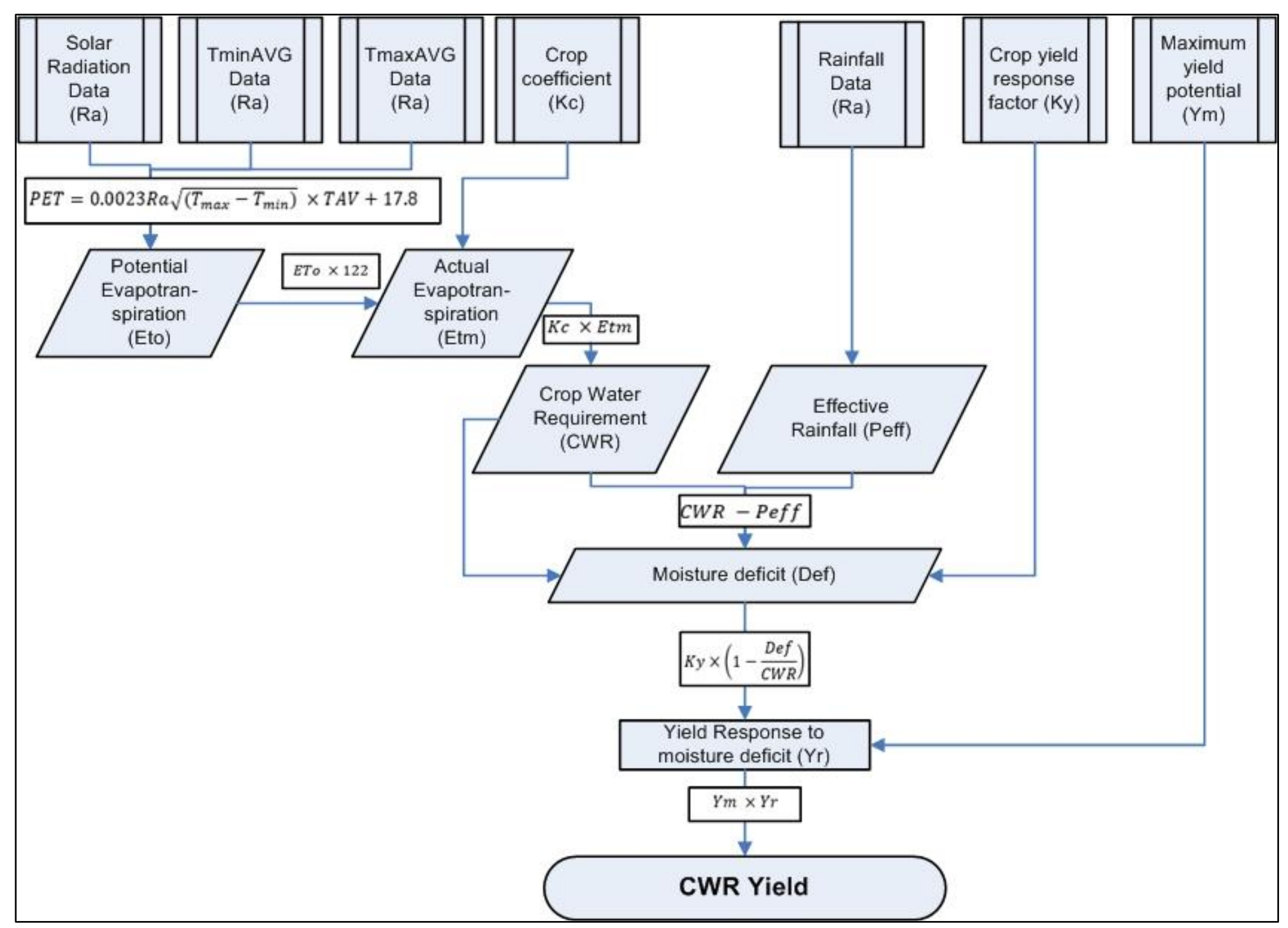

Figure 5: Flowchart for yield estimation using CROWRAYEM 

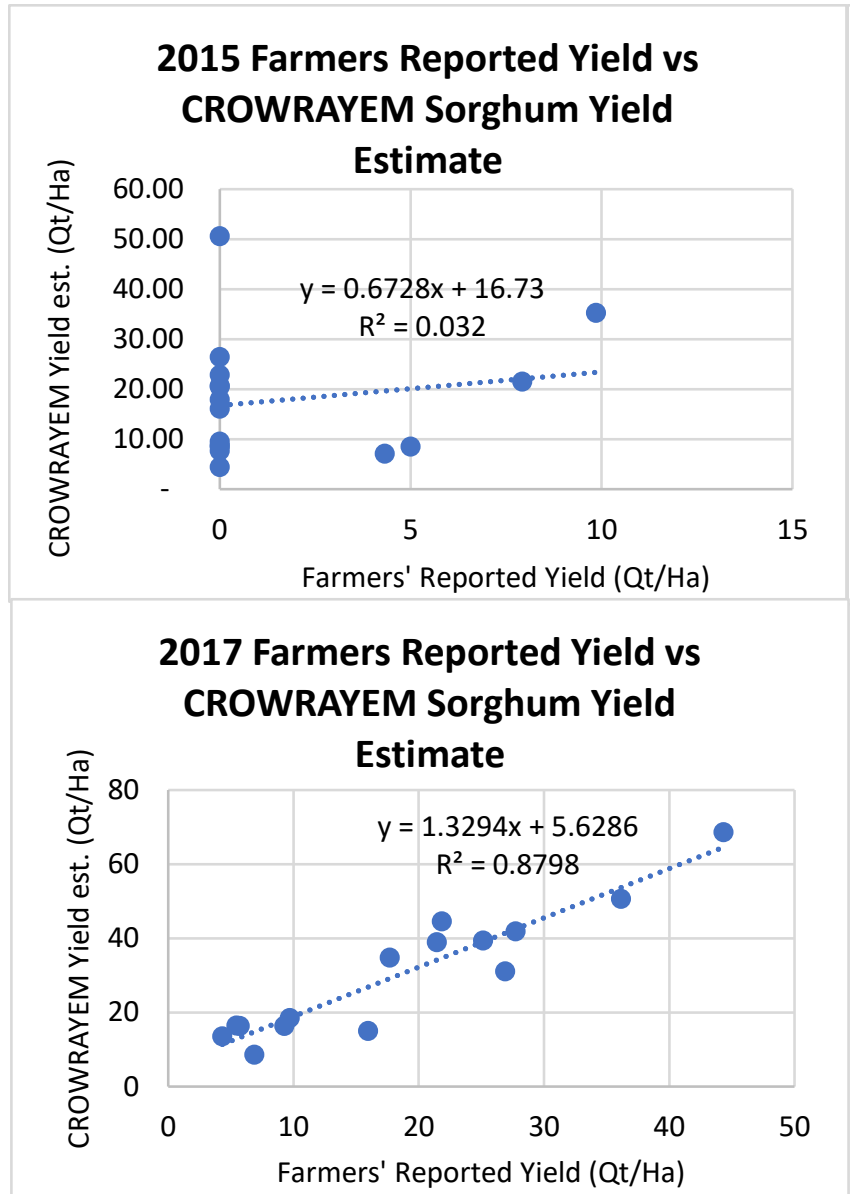
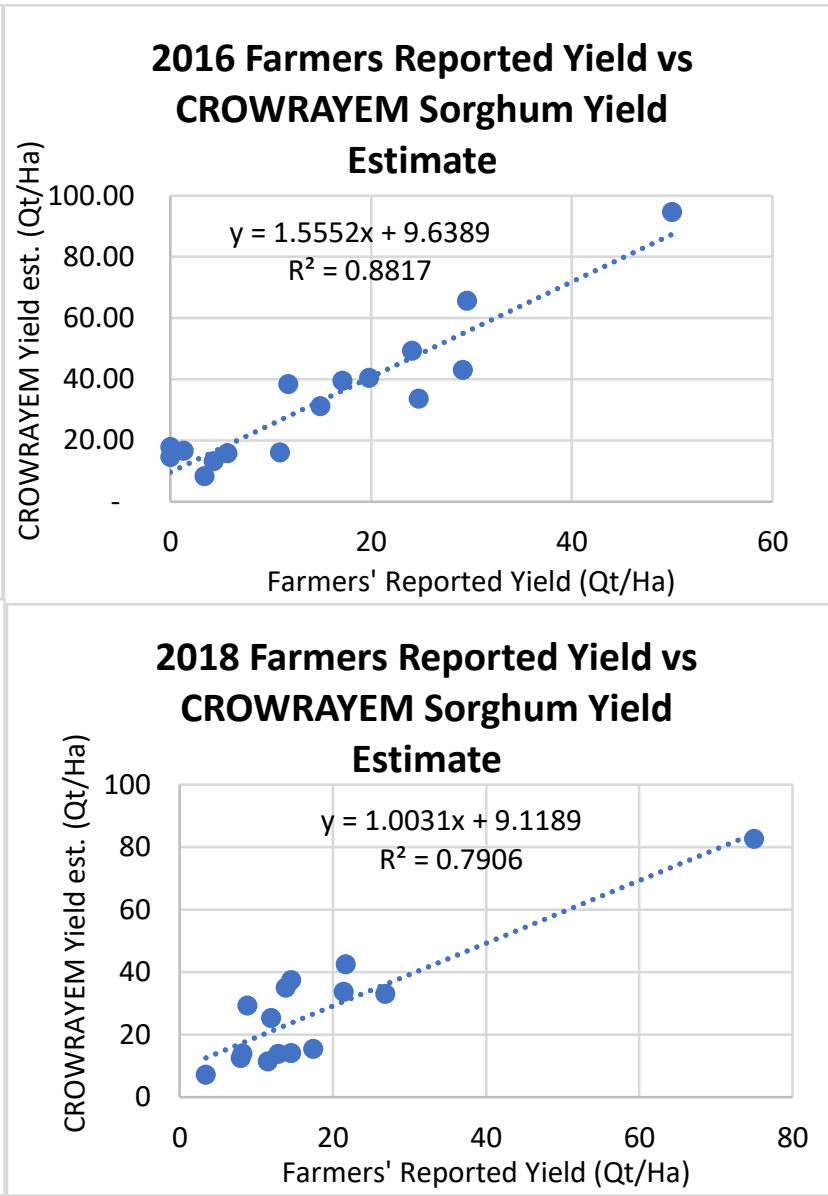

Reported Yield vs CROWRAYEM Sorghum Yield Estimate(2015 to 2018)

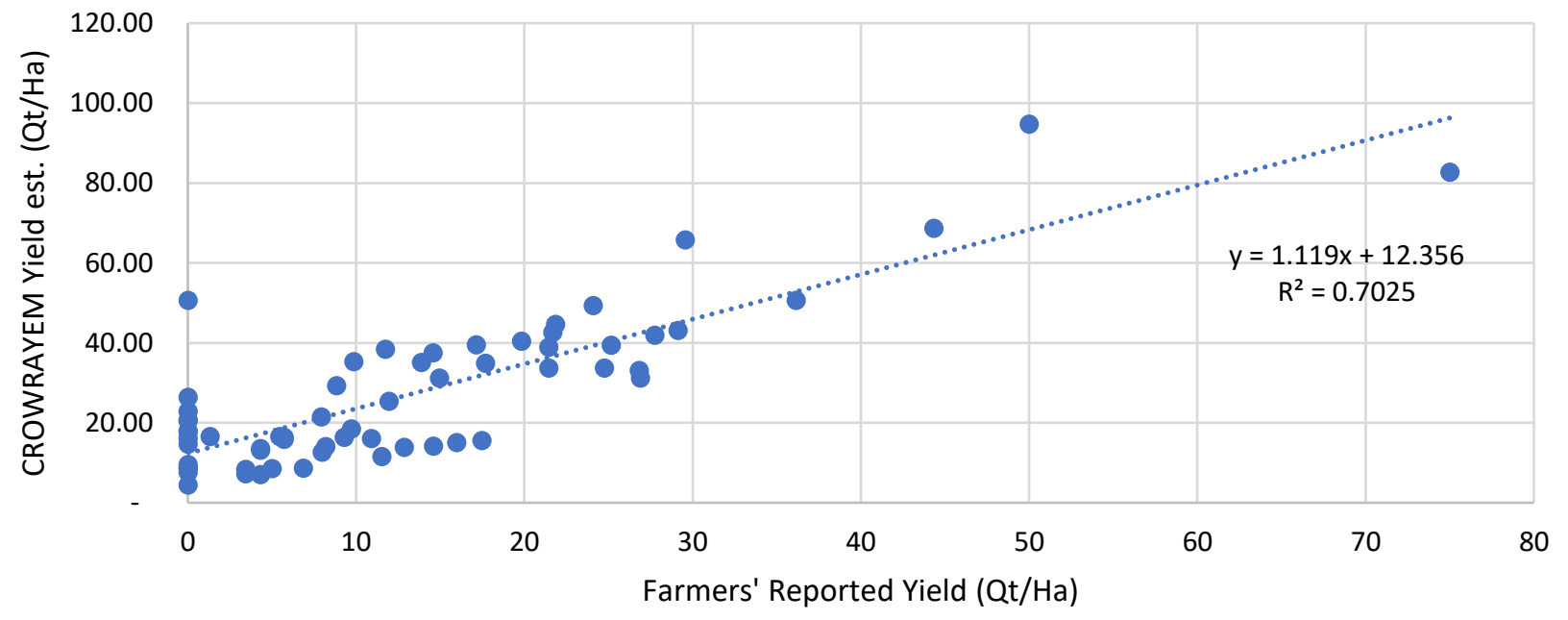

Figure 6: Farmers' reported yield vs CROWRAYEM estimated yield for sorghum 

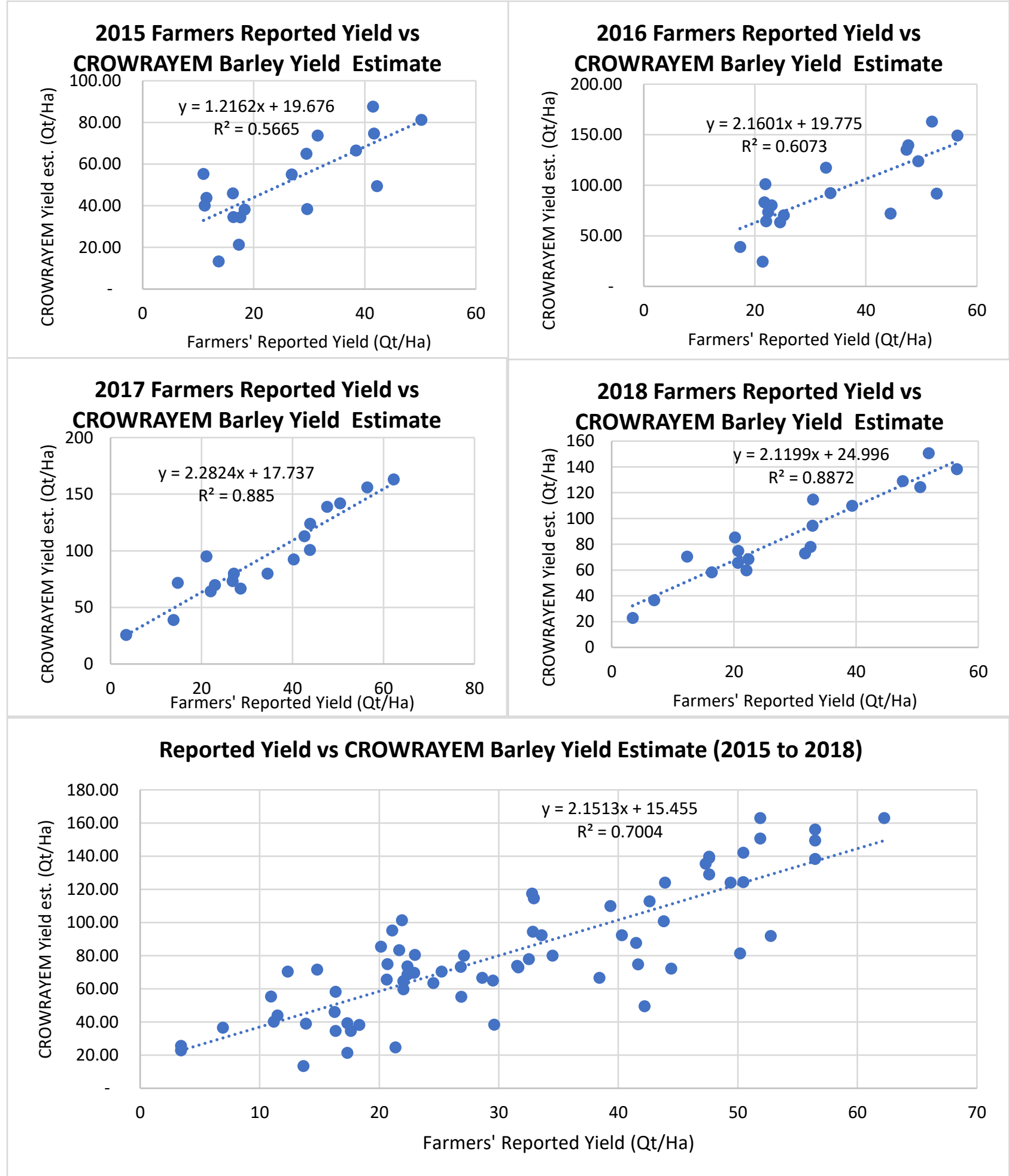

Figure 7: Farmers' reported yield vs CROWRAYEM estimated yield for barley 


\subsection{Evaluation of the performance of the crop water requirement analysis yield estimation model (CROWRAYEM)}

Table 3 presents different spatiotemporal performances of the CROWRAYEM in estimating sorghum and barley yield in the study area. The model performance for sorghum crops in Raya Azebo, is quite poor in 2015, but estimates higher and better in years of mild drought and normal precipitation. This is evident by the very low coefficient of determination $\left(\mathrm{R}^{2}\right)$ and index of agreement $(d)$ and is good in years of (above)normal precipitation and yield. For barley estimate in Endamekhoni, the evaluation indices present diverse results, but the coefficient of determination $\left(\mathrm{R}^{2}\right)$ indicate a moderate to good estimation of the farmers' yield.

Table 3: Statistical evaluation of CROWRAYEM estimated and farmers' reported crop yield

\begin{tabular}{|c|c|c|c|c|c|c|}
\hline \multirow{2}{*}{$\begin{array}{l}\text { Location/ } \\
\text { Crop }\end{array}$} & \multirow{2}{*}{$\begin{array}{l}\text { Model Evaluation } \\
\text { Statistics }\end{array}$} & \multicolumn{4}{|c|}{ Years } & \multirow[b]{2}{*}{ ALL } \\
\hline & & 2015 & 2016 & 2017 & 2018 & \\
\hline & R-square & 0.03 & 0.88 & 0.87 & 0.79 & 0.70 \\
\hline Raya Azebo: & RMSE & 19.94 & 21.07 & 13.19 & 12.06 & 17.30 \\
\hline \multirow[t]{2}{*}{ Sorghum } & MAE & 16.18 & 18.21 & 11.13 & 8.91 & 14.04 \\
\hline & $\operatorname{IA}(d)$ & 0.06 & 0.71 & 0.82 & 0.88 & 0.743 \\
\hline \multirow{4}{*}{ Endamekhon } & R-square & 0.56 & 0.60 & 0.88 & 0.89 & 0.70 \\
\hline & RMSE & 28.60 & 65.63 & 65.11 & 60.93 & 57.17 \\
\hline & MAE & 24.38 & 57.74 & 60.57 & 57.32 & 50.70 \\
\hline & $\mathrm{IA}(d)$ & 0.48 & 0.262 & 0.341 & 0.344 & 0.35 \\
\hline
\end{tabular}




\subsection{Application of the use of CROWRAYEM estimated yields for insurance payouts}

The outputs of the CROWRAYEM model were applied as yield inputs in determination of insurance payouts, based on the area yield index insurance payout structure (equation 5) used by (Choudhury et al., 2016; Eze et al., 2020), to estimate payouts for the 2016 cropping season. The area yield index insurance payout structure operates the principle of proportional payouts in lieu of crop losses. Crop yield within the threshold attracted appropriate payouts commensurate to the crop losses predicted.

Payout $=\left\{\begin{array}{cc}I A, & \text { if } I_{A} \leq I_{E} \\ I A & \times\left(\frac{I_{T}-I_{A}}{I_{T}-I_{E}}\right) \text { if } I_{E}<I_{A} \leq I_{T} \\ 0, & \text { if } I_{A} \geq I_{T}\end{array}\right.$

Results of the infusion of the yield outputs of CROWRAYEM into the insurance payout structures (Figure 8) shows a strong application of the crop water requirement in estimating yields, and the use of same in the determination of appropriate insurance payouts for due compensation of crop losses. 

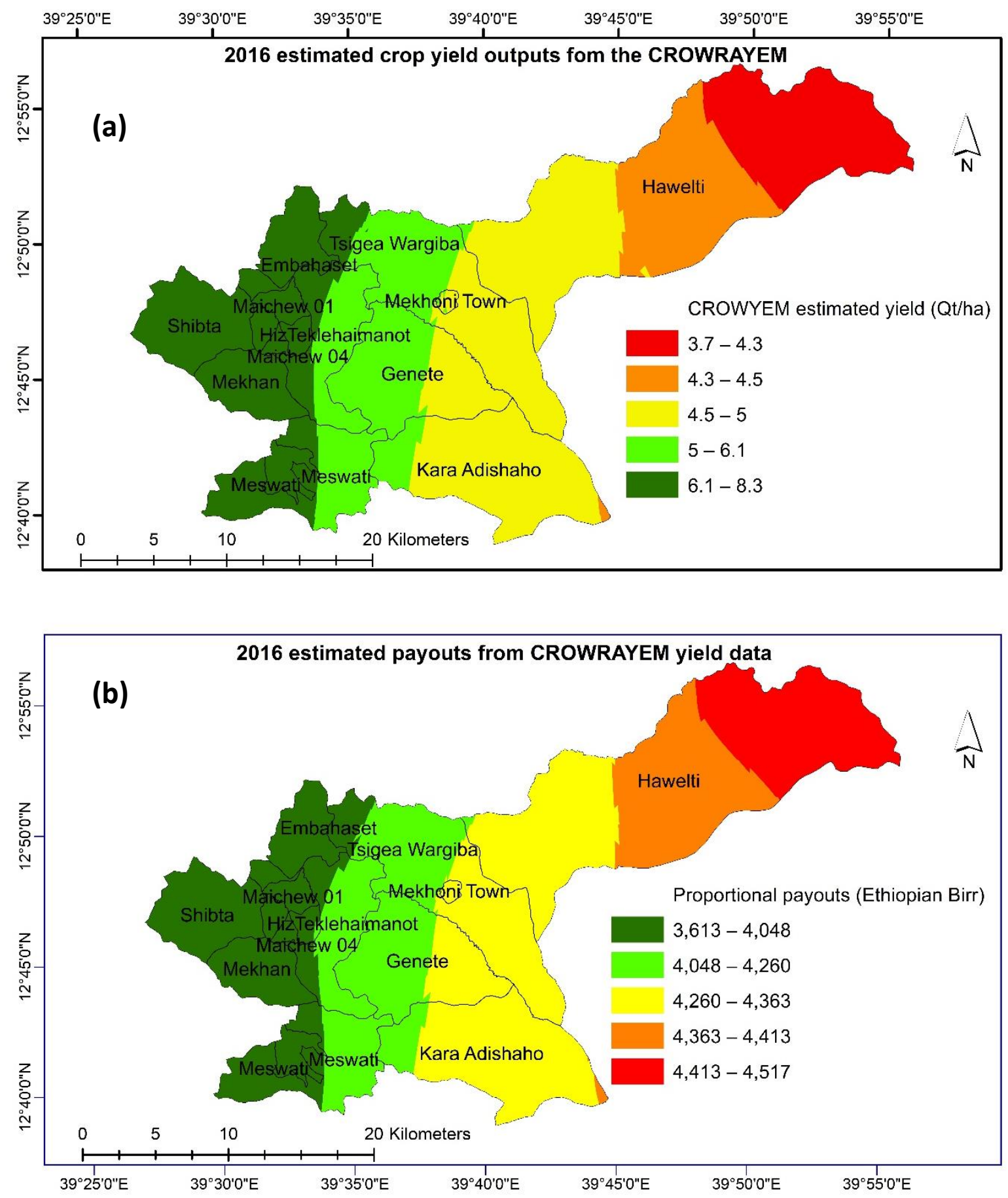

Figure 8: (a) Yield output from the CROWRAYEM (b) proportional area yield insurance index payouts based on the estimated yield data from the CROWRAYEM 


\section{Discussion}

Results of this study indicate that both CROPWAT 8.0 software and CROWRAYEM models are applicable in the estimation of crop yields (barley and sorghum) remotely. In terms of the performance of the models, they obtain a highly accurate estimate of both barley and sorghum yields during years of adequate precipitation and normal/above-normal yield. However, during years of extreme drought (full crop losses) the yield estimates from both models are weakly correlated to farmers' reported yield. The multiple full crop losses in 2015 recorded in the lowland area of Raya Azebo weakened the performance of the models in estimating crop yield. None of the models was accurate in estimating any farmer's yield as ' $0 \mathrm{Qt} / \mathrm{ha}$ ' for the said year.

The overall model evaluation statistics, especially for the CROWRAYEM, indicates prospects of improvements on the model's ability to estimate crop yields, owing to its high accuracy (Table 3). All statistics used in evaluating the yield estimates for sorghum, which is the crop for the lowland area of Raya Azebo, for the years under review had an overall promising performance, which is likely to improve further, with more accurate yield data from farmers or other agricultural agencies. On the other hand, the barley yield estimates, from the highland areas, show a gradually improving coefficient of determination (56\% to $89 \%$ ), but other evaluation parameters applied indicate a weak performance of the model. A question arises as to other factors unconsidered by this study has impact on crop yield, and should be considered for incorporation in crop yield models. Factors such as agro-ecology of an area, in addition to other strong factors of crop yield outlined by (Batchelor et al., 2002) such as plant genetics, crop population, and crop management, have not been considered in this study. Also, heterogeneous crop performance within a plot raised by (Sapkota et al., 2016), were not incorporated into the yield estimation model, which could also affect its accuracy. 
For drought-prone Raya Azebo, the ability of these crop water requirements-based yield estimation models in providing approximate yield data is of great importance. Since it has been given by (Abera et al., 2019), climate change adversely affects water availability in Northern Ethiopia, in which Raya Azebo falls, such mechanisms of yield estimation as developed in this study could be adapted as a decision tool for investors. Insurance companies could leverage on this possibility to establish their yield estimation mechanisms, to reduce cost of physical travels for verification of crop losses each farming season. Hence, determination and affirmation of crop losses recorded by farmers for compensation during droughts within the area-yield-index-insurance framework can be easily achieved.

\section{Conclusion}

This study has demonstrated that barley and sorghum farmers' yield can be estimated using CROPWAT 8.0 and CROWRAYEM models, with a strong relationship found between obtained farmers' historical yield and model estimations. This approach has also been successfully applied to determination of payouts remotely, which has prospects of reduction of physical trips to farms and other related costs for verification of crop losses, thus increasing the possibility of a fully automated approach to crop insurance (especially the area-yield-index-insurance).

The prospect of the developed CROWRAYEM to predict yield and yield loss is feasible. With availability of improved historical crop yield data and adequate soil tests, farmers' yield can be accurately predicted to determine yield losses and required compensation for farmers in the context of area yield index insurance. Furthermore, a reassessment of accurate historical data, and comparison of the same with the output of the CROWRAYEM is likely to provide a stronger evidence for the efficiency of the model. 


\section{Limitations and further research}

This study has apparent limitations in terms of length of yield data and a meagre sample size. This reduces the generalizability of its findings, and results herein cannot be directly applied to other places outside of the study area. Required time series data for crop yield at ward and district levels were unavailable at the agricultural and statistics' offices, hence our improvisation for data acquisition. Furthermore, certain strict criteria necessitated the trimming of the sample size, such as farmers who cultivate the specified crops as their major crops, and who could easily recall yields obtained in four previous seasons. With the availability of comprehensive time series crop yield data at ward levels, increased accuracy of yield data obtainable from surveys could improve the findings of the study. More so, if future research in the area could include soil tests to increase

accuracy in detecting the yield loss rates from CROPWAT 8.0. Also, there is the likelihood of developing a regression model to include other factors that affect crop yields in drylands, for yield prediction.

\section{Acknowledgments}

The grid meteorological data provided by Ethiopia National Meteorological Agency (NMA) and International Research Institute for Climate and Society, Columbia, were indeed helpful. The rural smallholders who willingly provided data are highly appreciated. 


\section{8. $\quad$ Funding}

This work is supported by the European Union's Transdisciplinary Training for Resource Efficiency and Climate Change Adaptation in Africa (TRECCAfrica II) project; and research fund from Institute of Climate and Society (ICS), Mekelle University, Ethiopia.

\section{Declaration of competing interests}

The authors hereby declare that they have no competing interests.

\section{References}

Abera, W., Tamene, L., Abegaz, A., Solomon, D., 2019. Understanding climate and land surface changes impact on water resources using Budyko framework and remote sensing data in Ethiopia. J. Arid Environ. 167, 56-64. https://doi.org/10.1016/j.jaridenv.2019.04.017

Allen, R.G., Pereira, L.S., Raes, D., Smith, M., 1998. Crop Evapotranspiration: Guidelines for Computing Crop Water Requirements (No. 56), FAO Irrigation and Drainage Paper. Italy, Rome.

Bana, S., Prijono, S., Ariffin, S. marno, 2013. Evaluation Crop Water Requirement on the Dryland at the West Bangkala Sub District of Jeneponto Regency. Int. J. Ecosyst. 3, 30-36. https://doi.org/10.5923/j.ije.20130303.03

Batchelor, W.D., Basso, B., Paz, J.., 2002. Examples of strategies to analyze spatial and temporal yield variability using crop models. Eur. J. Agron. 18, 141-158.

Bayissa, Y.A., 2018. Developing an Impact-Based Combined Drought Index for Monitoring Crop Yield Anomalies in the Upper Blue Nile Basin, Ethiopia. Delft University of Technology. 
Berhane, G., Gebrehiwot, A., Berhe, K., Hoekstra, D., 2010. Commercialization of vegetable production in Alamata Woreda, Northern Ethiopia: Processes and Impact.

Bhat, S.A., Pandit, B.A., Khan, J.N., Kumar, R., Jan, R., 2017. Water Requirements and Irrigation Scheduling of Maize Crop using CROPWAT Model. Int. J. Curr. Microbiol. App. Sci. 6, 1662-1670. https://doi.org/https://doi.org/10.20546/ijcmas.2017.611.199

Chai, T., Draxler, R.R., 2014. Root mean square error (RMSE) or mean absolute error (MAE)? Arguments against avoiding RMSE in the literature. Geosci. Model Dev. 7, 1247-1250. https://doi.org/10.5194/gmd-7-1247-2014

Choudhury, A., Jones, J., Okine, A., Choudhury, R.L., 2016. Drought-Triggered Index Insurance Using Cluster Analysis of Rainfall Affected by Climate Change. J. Insur. Issues 39, 169186.

Clarke, D., 2017. Assessing the impacts of drought on UK wheat production. Cranfield University.

Clarke, D.J., 2016. A Theory of Rational Demand for Index Insurance. Am. Econ. J. Microeconomics 8, 283-306. https://doi.org/http://dx.doi.org/10.1257/mic.20140103

Ewaid, S.H., Abed, S.A., Al-Ansari, N., 2019. Crop Water Requirements and Irrigation Schedules for Some Major Crops in Southern Iraq. Water 11, 12. https://doi.org/10.3390/w11040756

Eze, E., Girma, A., Zenebe, A.A., Zenebe, G., 2020. Feasible crop insurance indexes for drought risk management in Northern Ethiopia. Int. J. Disaster Risk Reduct. 47, 1-11. https://doi.org/10.1016/j.ijdrr.2020.101544

Funk, C.C., Peterson, P.J., Landsfeld, M.F., Pedreros, D.H., Verdin, J.P., Rowland, J.D., Romero, B.E., Husak, G.J., Michaelsen, J.C., Verdin, A.P., 2014. A Quasi-Global 
Precipitation Time Series for Drought Monitoring, Data Series 832.

Gebrechorkos, S.H., Hulsmann, S., Bernhofer, C., 2018. Evaluation of Multiple Climate Data Sources for Managing Environmental Resources in East Africa. Hydrol. Earth Syst. Sci. 22, 4547-64. https://doi.org/doi.org/10.5194/hess-22-4547-2018

International Research Institute for Climate and Society, 2016. Why ENACTS? Training module (No. 1.0), ENACTS: ENHANCED NATIONAL CLIMATE SERVICES.

Jones, J.R., Choudhury, A., Domingo, J., Spaulding, A., Ostaszewski, K., Amamoo, G., Melton, H., Danso-Manu, M., Bill, R., Mahd, M., Odilov, A., 2011. Establishing an index insurance triggers for crop loss in Northern Ghana (No. Research Paper No. 7).

Khan, M.I., Walker, D., 2015. Application of Crop Growth Simulation Models in Agriculture with special reference to Water Management Planning. Int. J. Core Eng. Manag. 2, 113130.

Liu, Hai-long, Liu, Hong-bin, Lei, Q., Zhai, L., Wang, H., Zhang, Ji-zong, Zhu, Y., Liu, S., Li, S., Zhang, Jing-suo, Liu, X., 2017. Using the DSSAT model to simulate wheat yield and soil organic carbon under a wheat-maize cropping system in the North China Plain. J. Integr. Agric. 16, 2300-2307. https://doi.org/10.1016/S2095-3119(17)61678-2

Loum, M., Viaud, V., Fouad, Y., Nicolas, H., Walter, C., 2014. Retrospective and prospective dynamics of soil carbon sequestration in Sahelian agrosystems in Senegal. J. Arid Environ. 100-101, 100-105. https://doi.org/10.1016/j.jaridenv.2013.10.007

Maurya, R.K., Yadav, S.K., Sharma, T.K., 2019. Estimation of Major Agricultural Crop with Effective Yield Prediction using Data Mining. Int. J. Innov. Technol. Explor. Eng. 8, 170174.

Miranda, M.J., Farrin, K., 2012. Index Insurance for Developing Countries. Appl. Econ. 
Perspect. Policy 34, 391-427. https://doi.org/10.1093/aepp/pps031

Sapkota, T.B., Jat, M.L., Jat, R.K., Kapoor, P., Stirling, C., 2016. Yield Estimation of Food and Non-food Crops in Smallholder Production Systems, in: T.S. Rosenstock, et al. (Ed.), Methods for Measuring Greenhouse Gas Balances and Evaluating Mitigation Options in Smallholder Agriculture. pp. 163-174. https://doi.org/10.1007/978-3-319-29794-1

Shuai, S., Fadong, L.I., Yonglong, L.U., Khan, K., Jianfang, X.U.E., Peifang, L., 2018. Spatiotemporal Characteristics of the Extreme Climate Events and Their Potential Effects on Crop Yield in Ethiopia. J. Resour. Ecol. 9, 290-301. https://doi.org/10.5814/j.issn.1674764x.2018.03.009

Shukla, S., Funk, C., Peterson, P., Mcnally, A., Dinku, T., Barbosa, H., Paredes-Trejo, F., Pedreros, D., Husak, G., 2017. The Climate Hazards group InfraRed Precipitation with Stations (CHIRPS) dataset and its applications in drought risk management. Geophys. Res. Abstr. 19.

Surendran, U., Sushanth, C.M., Mammen, G., Joseph, E.J., 2017. FAO-CROPWAT model-based estimation of crop water need and appraisal of water resources for sustainable water resource management: Pilot study for Kollam district - humid tropical region of Kerala , India. Curr. Sci. 112, 76-86.

Willmott, C.J., 1981. On the validation of models. Phys. Geogr. 2, 184-194.

Willmott, C.J., Matsuura, K., 2005. Advantages of the mean absolute error (MAE) over the root mean square error (RMSE) in assessing average model performance. Clim. Res. 30, 79-82. Yazew, E., Gebru, T., G/Egziabher, T., Mezgebu, A., Fessehaye, D., Habtu, S., Haile, A., Steenbergen, F. van, Wester, F., 2012. Spate Irrigation Systems in Raya Valley (Ethiopia) (No. 13), Overview Paper. 


\section{Footnotes}

${ }^{1}$ Environmental Policy Integrated Climate (EPIC) model

${ }^{2}$ Decision Support System for Agro-Technology Transfer (DSSAT) model 


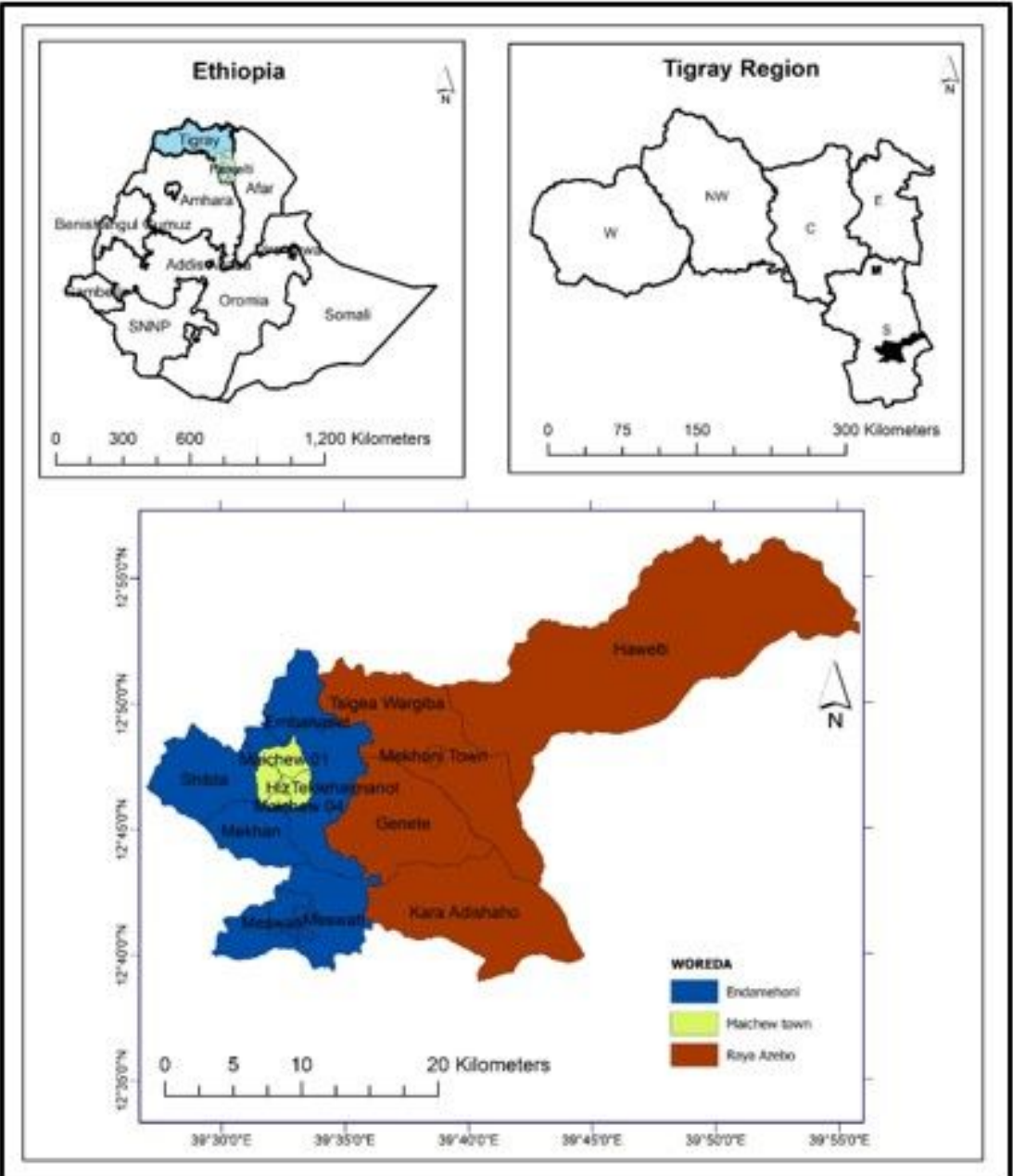

Figure 1: Study area map

\section{Figure 1}

Study area map

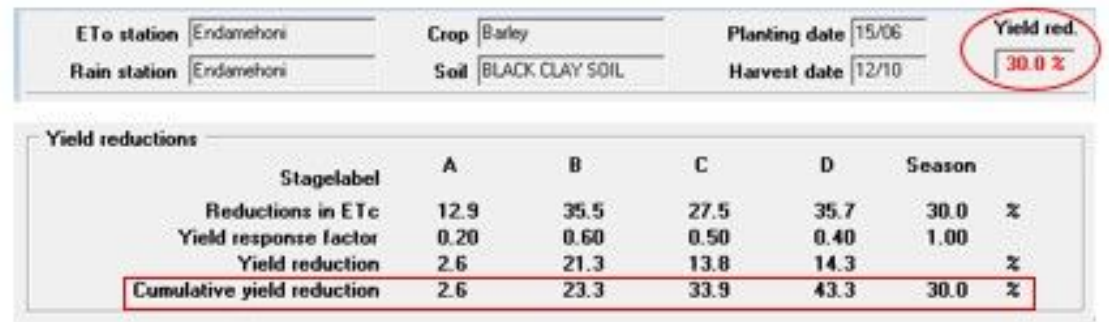

Figure 2: Results of interest in the crop irrigation schedule of CROPWAT 8.0

\section{Figure 2}

Results of interest in the crop irrigation schedule of CROPWAT 8.0 


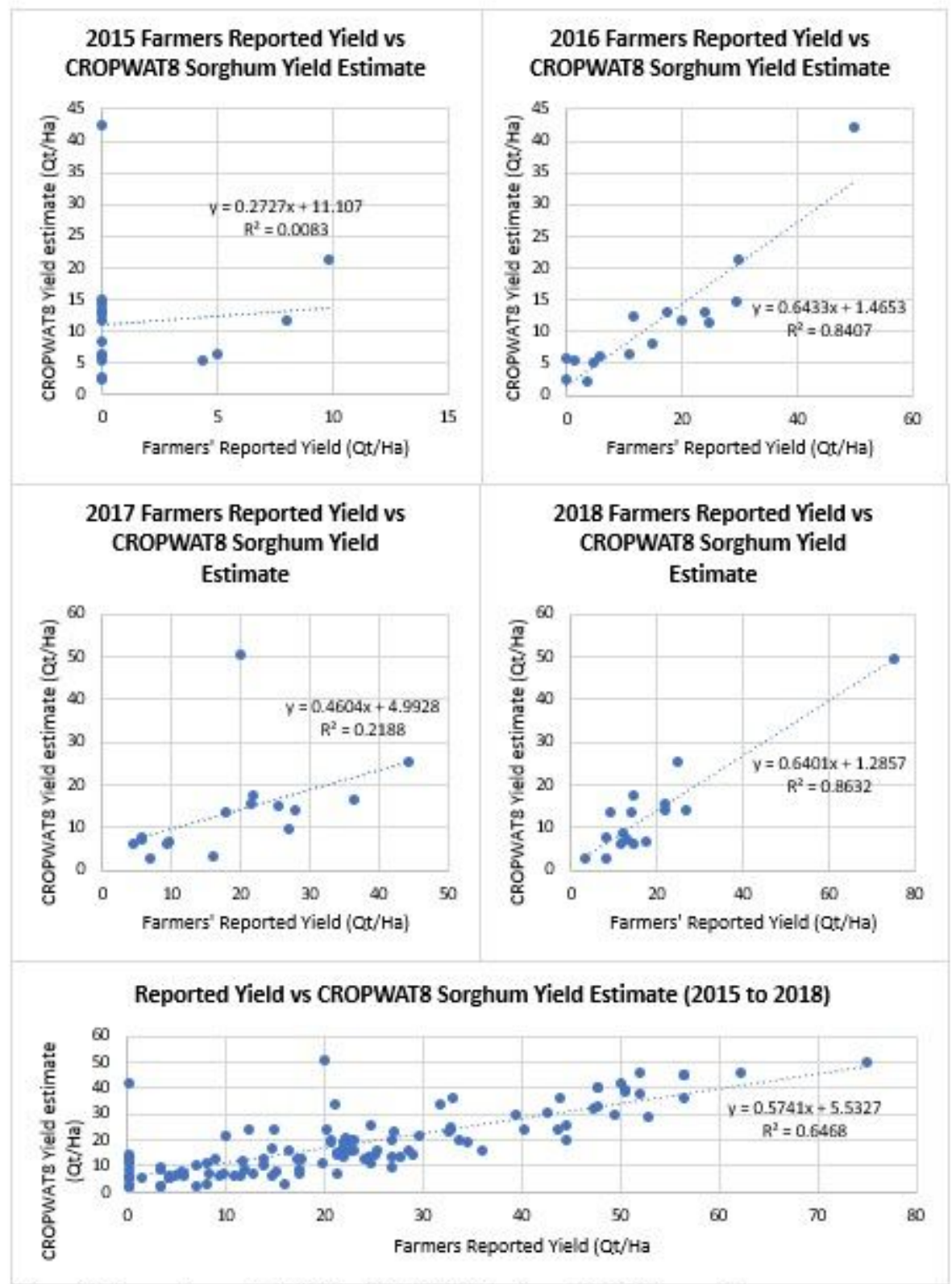

Figure 3: Farmers' reported yield vs CROPWAT estimated yield for sorghum

\section{Figure 3}

Farmers' reported yield vs CROPWAT estimated yield for sorghum 


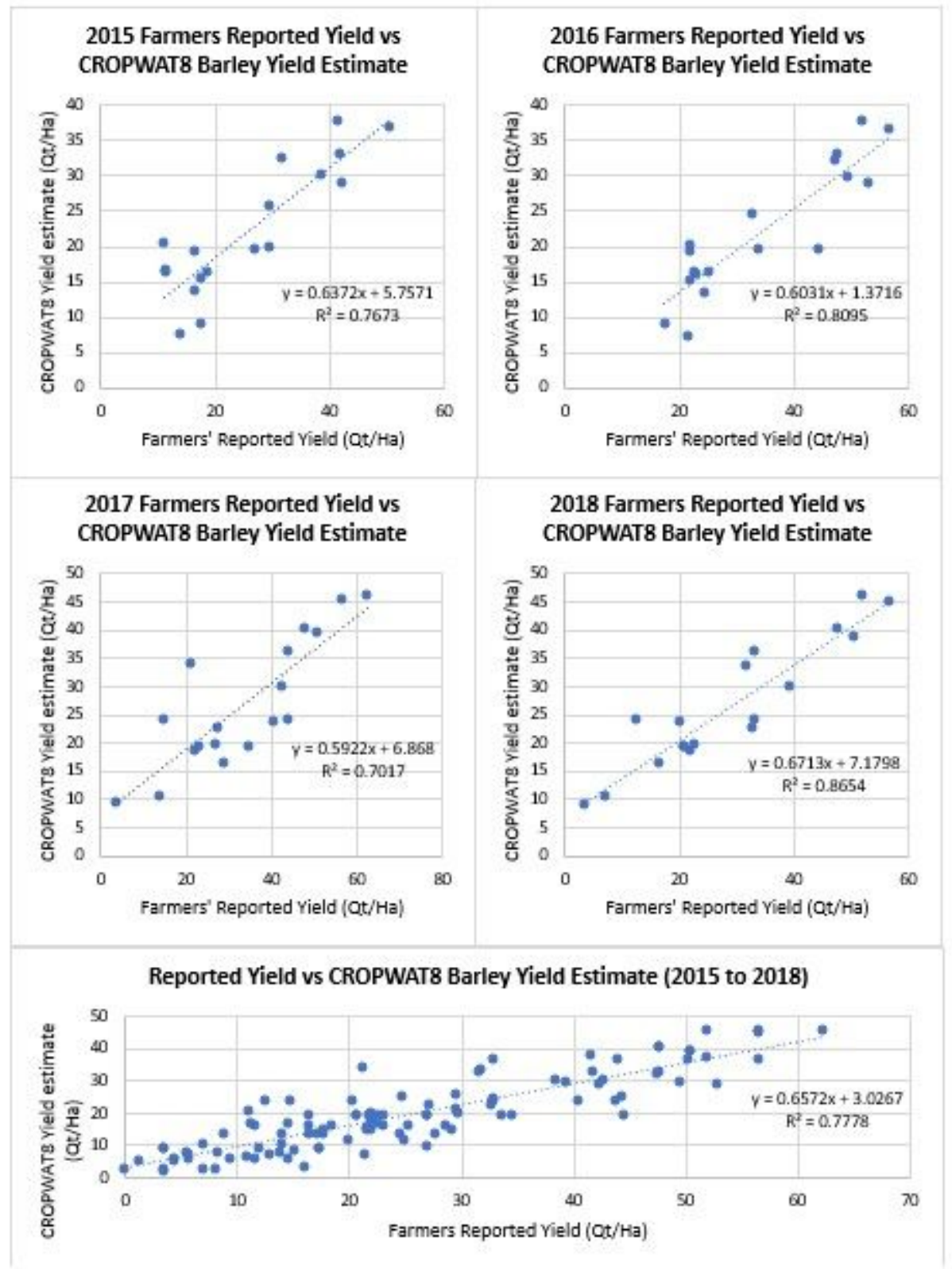

Figure 4: Farmers' reported yield vs CROPWAT estimated yield for barley

\section{Figure 4}

Farmers' reported yield vs CROPWAT estimated yield for barley 


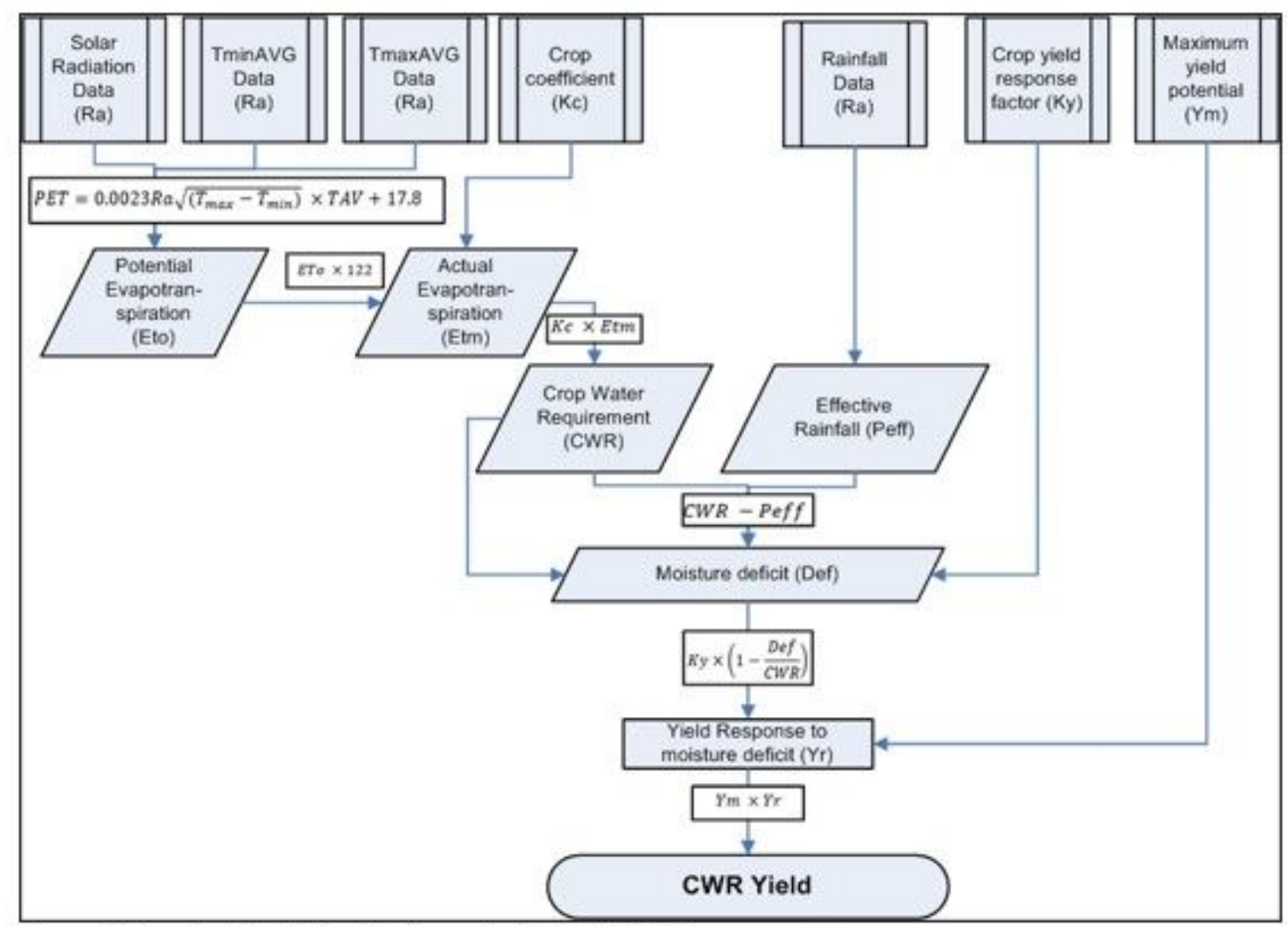

Figure 5: Flowchart for yield estimation using CROWRAYEM

\section{Figure 5}

Flowchart for yield estimation using CROWRAYEM 


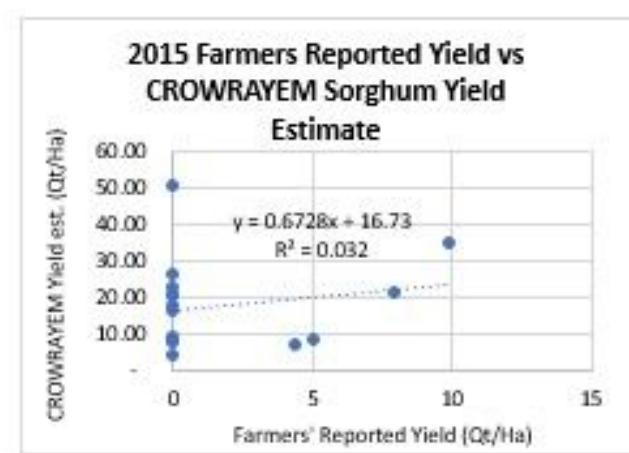

2017 Farmers Reported Yield vs CROWRAYEM Sorghum Yield

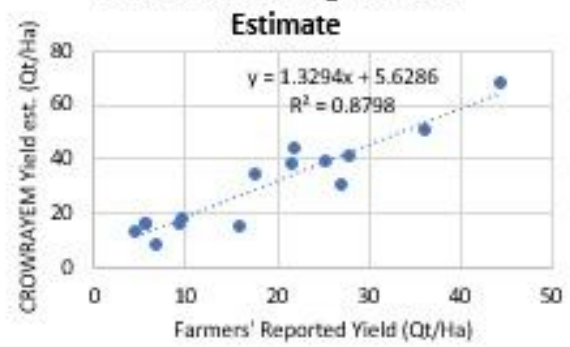

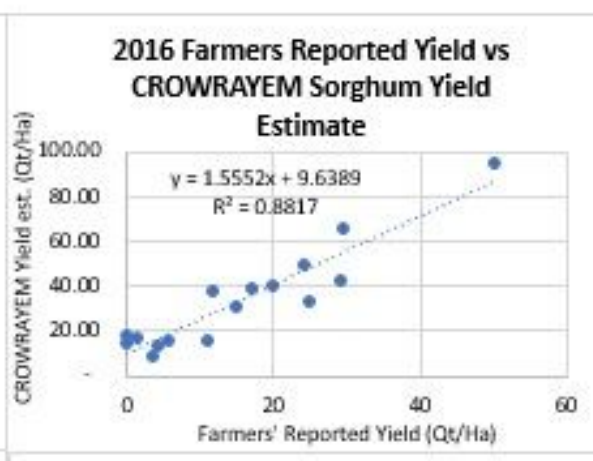

2018 Farmers Reported Yield vs CROWRAYEM Sorghum Yield

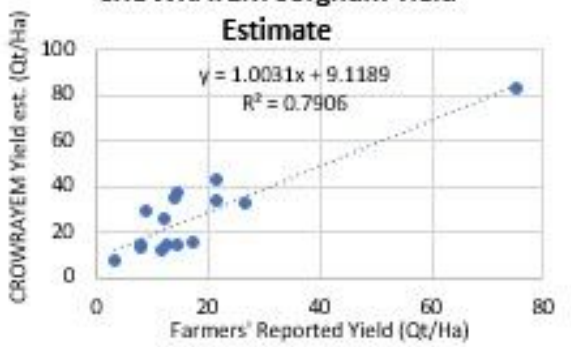

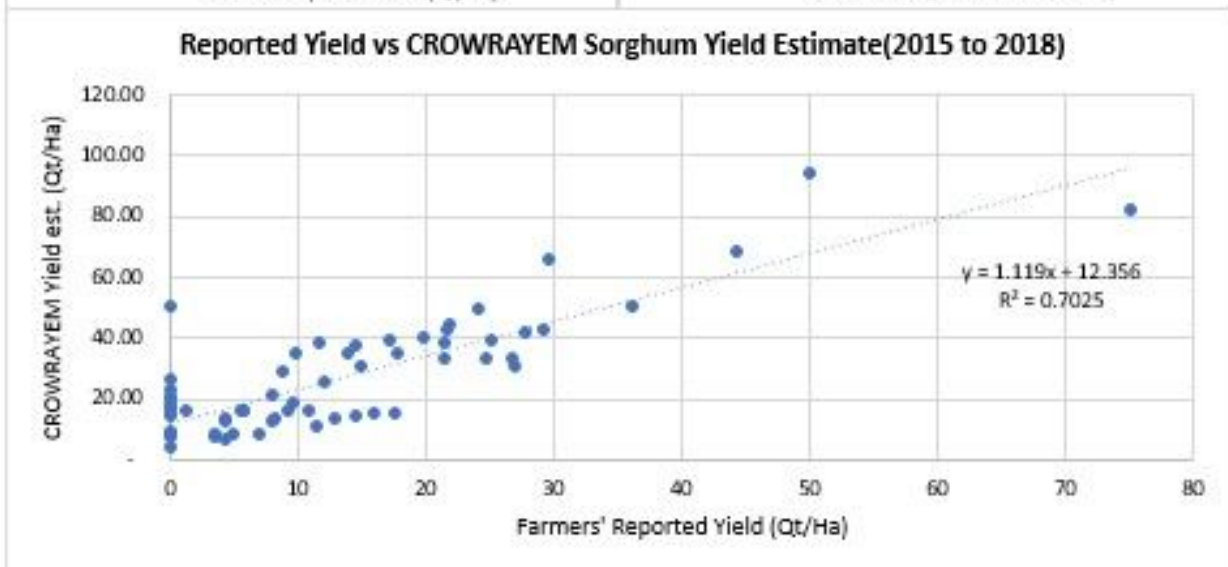

Figure 6: Farmers' reported yield vs CROWRAYEM estimated yield for sorghum

\section{Figure 6}

Farmers' reported yield vs CROWRAYEM estimated yield for sorghum 


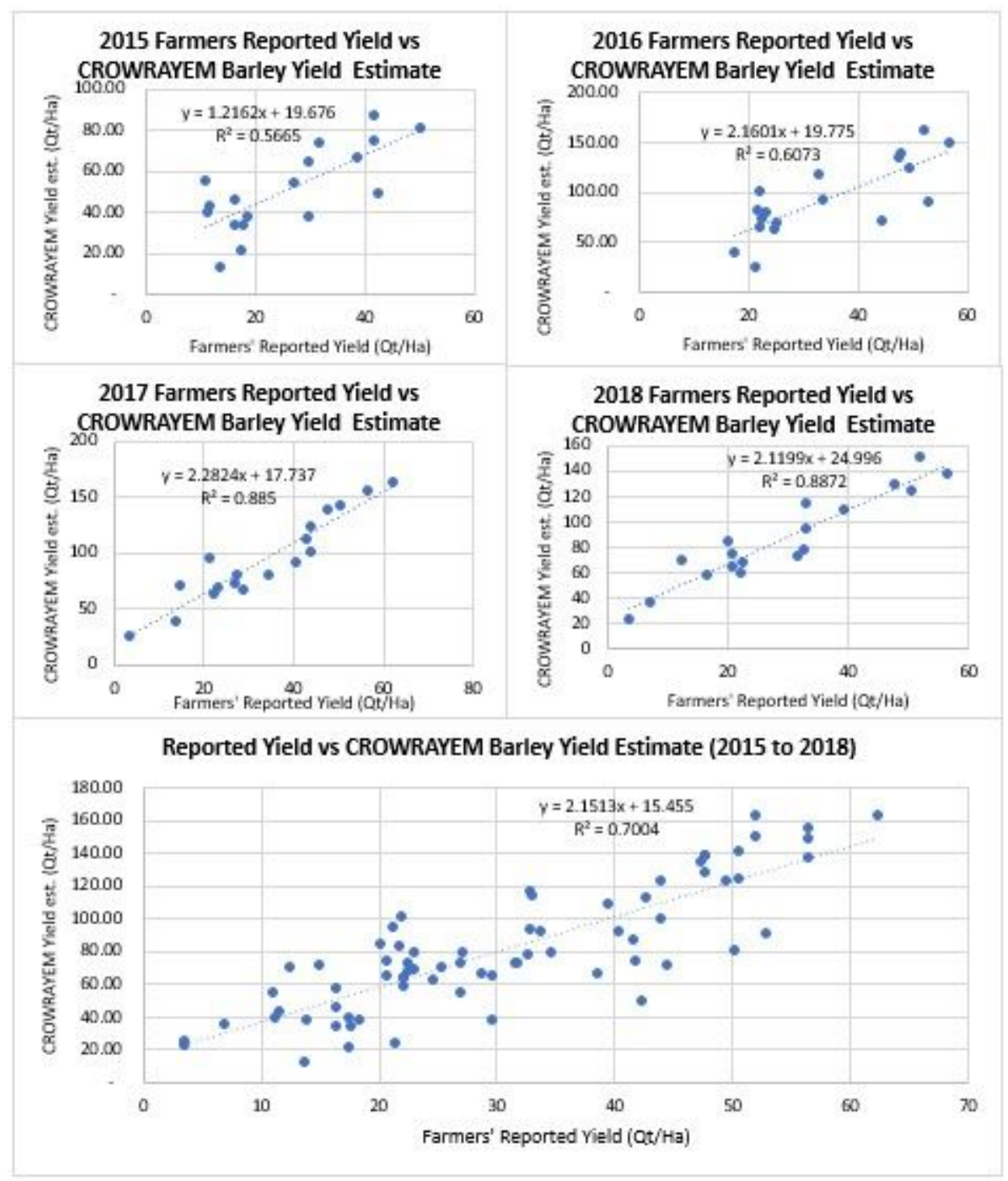

Figure 7: Farmers' reported yield vs CROWRAYEM estimated yield for barley

\section{Figure 7}

Farmers' reported yield vs CROWRAYEM estimated yield for barley 

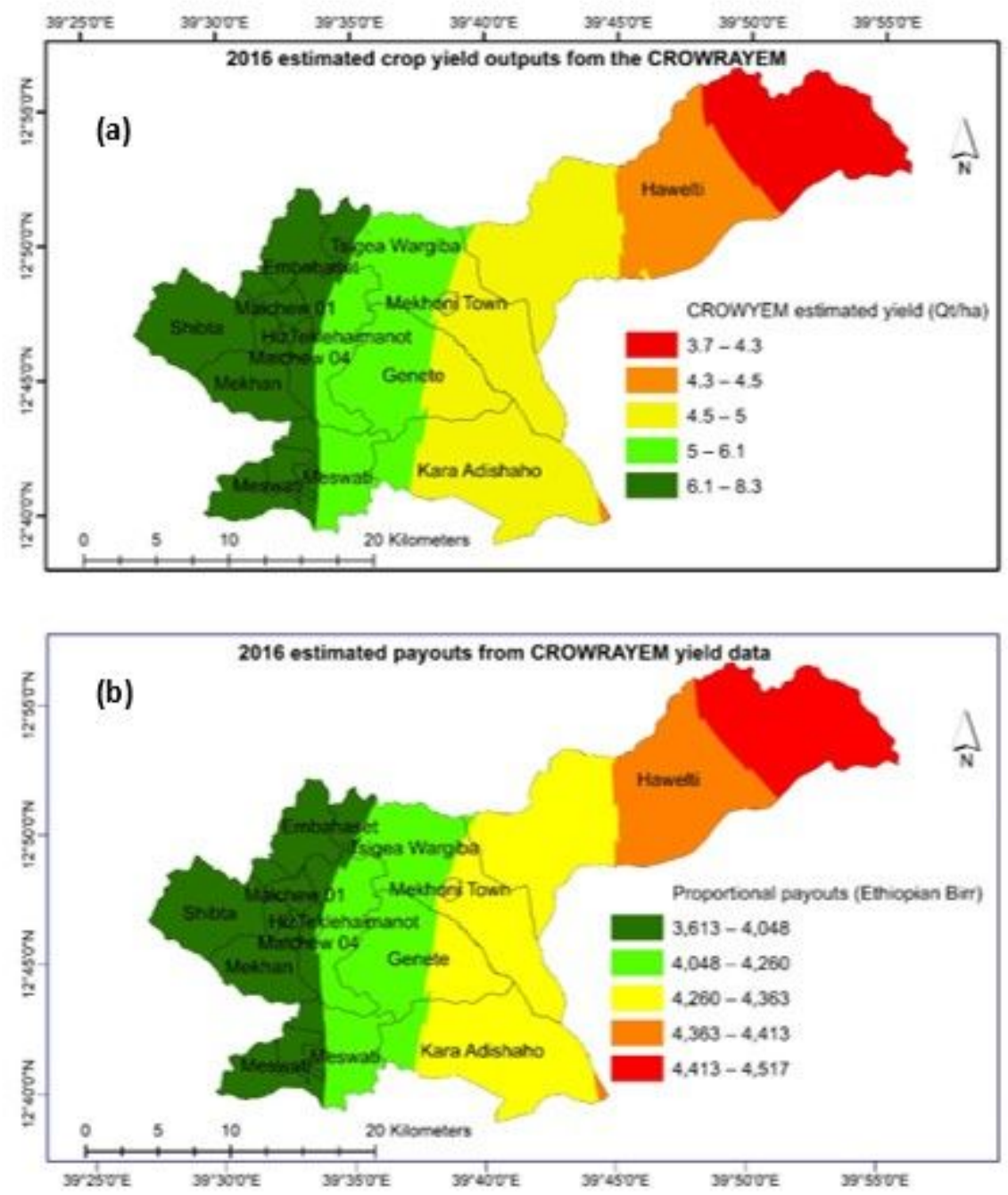

Figure 8

(a) Yield output from the CROWRAYEM (b) proportional area yield insurance index payouts based on the estimated yield data from the CROWRAYEM 